\title{
The Great War in Poland-Lithuania from a Jewish Perspective: Modernization and Orientalization
}

\author{
Martin Ernst Rudolf Arndt \\ Department of Philosophy, University of Zagreb, Croatia \\ Email: martarndt@web.de
}

\begin{abstract}
The article presents views of Eastern Judaism, especially in Lithuania, in the Jewish press around the Great War. It is based on a close research of journals, newspapers and book-publications written in the German language. It evidences the global implications of the Great War due, among others, to forced and voluntary migrations that involved cultural encounters, confrontations and challenges. The Other, signifying a collective excluded from the social whole, in those days perceived in the Eastern Jew, meant an embarrassment to the Western Jews (Albanis: 30) and served the function of constructing self-identity, involving them in conflicts or making them develop a dual allegiance (Moshe Gresser; Albanis). Should Jews, if they were to become proper Europeans, not decisively shed their Asian being and carriage and thus de-orientalize themselves? The paper also demonstrates that this historical phase of Jewish history, as it deeply involves the problem of secularization, is connected to intricate problems of identity. It can also illustrate a certain openness and fluidity of identitarian possibilities. The issues involved have a clear relevance for contemporary societies, centred around the question if modernity requires minorities to surrender their particularism, or if is there a suble dialectic between universalism and particularism. Implicitly the core issue also raises the question of a common history of Islam and Judaism and the current problem if antisemitism as targeted at the Eastern Jews is comparable to contemporary Islamophobia.
\end{abstract}

Keywords: colonialism; culture; globalization; Great War; identity; Jihad; Judaism; modernity; secularization; urbanisation

\section{INTRODUCTION}

Many contemporary publications focus on the meeting of East and West. The difference between East and West is, however, not a question of a few degrees of longitude east or west of any particular meridian: From the point of view, e.g., of an Italian, Marrakesh is certainly in the East, Sydney in the West; to Athenians of the $5^{\text {th }}$ century the East meant Asia and the Persian Empire, whereas a thousand years later Athens itself, and Byzantium and Alexandria, had become part of the East. Natural frontiers seem to shift like the others. Do spaces ontologically exist or are they constructed? Can we say that "Eastern" means essentially "non-European?" This would certainly ignore parts of history, as for parts of history the East was in Europe, and the Jews, seen as antimodern Orientals, live in Europe (Dingsdale: 23ff.). With the foundation of the German-Jewish liberal journal Der Orient : Berichte, Studien und Kritiken für jüdische Geschichte und Literatur / Literaturblatt des Orients (The Orient: Reports, Studies and Criticisms for Jewish History and Literature) in 1840 , devoted to the scientific study of Jewish literature and culture, and the period of great Jewish cultural creativity under Islamic rule, the association between Judaism and the Orient, though not completely new, had received publicity, and was further famously promulgated in the middle of the 19th century (Aschheim1: 84; Grosmann:202f.) with a clear eurocentric slant by the Jewish writer K. E. Franzos (1848-1904) who coined the term 'Halb-Asien' (=Demi-Orient, comprising the land 
Figure 1. The Map of Eastern Europe.

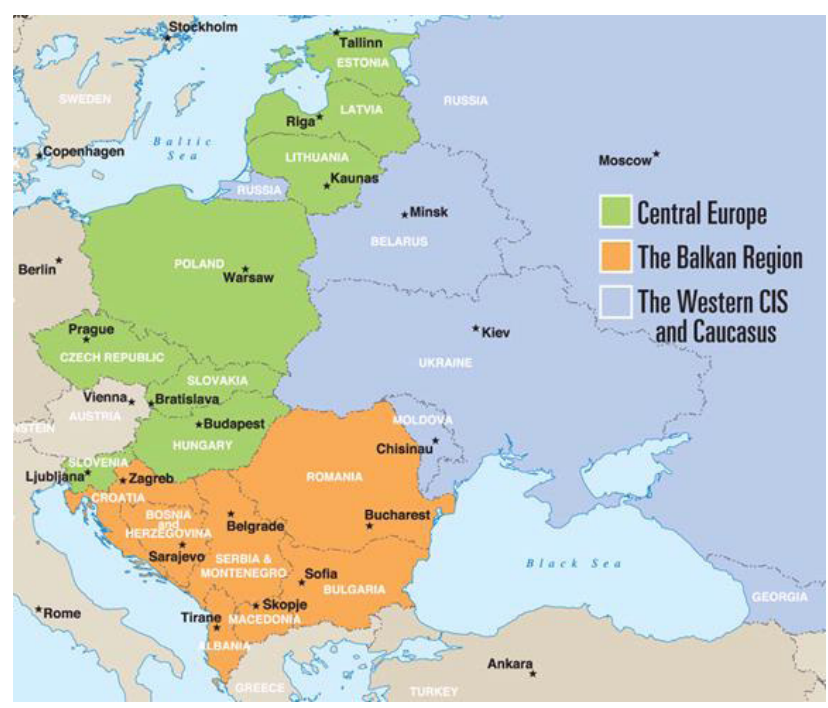

Source: https://siteselection.com/issues/2010/jul/images/ EasternEuropeMap_19684_2.jp

and people of Eastern Europe-Dingsdale: 93). Eastern Jews became not only the internal outsider, but also the imagined Orientals, and revitalized a dichotomy that dates back to antiquity. The encounter of these Eastern-Jewish 'oriental'-like people and Westerners, due to the influx of Eastern Jews into Germany at the end of the $19^{\text {th }}$ century and to confrontation on the battle-fields during the Great War, is both a fascinating and illuminating part of modern history. The countries of these Eastern Jews' origin cover a large geographic area (figure 1). From an even more Eastern and Asian perspective, they have been a remote part of the world. Although the Jewish rabbi Jacob Halevy Saphir (1822-1886) had published his report on his visit to 'Batavia' even in his birthplace Vilnius (Wilna), and although Jews had been present in Java and Sumatra as part of a cosmopolitan Jewish traders' network even before the arrival of European colonialists (Hutter: 41; The Jewish Community), and had arrived in Indonesia in the 17th century with the Dutch East India Company. there is no denying that the history of Europe and, even more, of Eurpean Jews are rather unknown and ignored beyond the American-European horizon.

\section{THE GREAT WAR - GLOBALIZATION}

The Great War from 1914 to 1918 was the first global war through the involvement of the colonial empires and their colonies, with non-Europeans serving in the armies both of the Allied (=Entente Powers: British Empire, the Russian Empire and France, later to be joined by China, Italy,
Japan, and the USA) and the Central Powers (= Quadruple Alliance: Germany, Austria-Hungary, the Ottoman Empire and Bulgaria). Though Southeast Asia's role in the Great War seems almost forgotten, it proved a decisive event also for that part of the world. The most interesting response to the declaration of war in 1914 was made by Siam, as Thailand was then known. As the only Southeast Asian nation not colonized by a European power, Siam, under the absolute monarch King Vajiravudh, decided to go to war against the Central Powers in 1917, after a German plot to organize a body of disaffected Indians in Siam to make an armed raid into Burma had shown that the Germans had compromised Siam's neutrality. The Siamese Expeditionary Force of more than 1,000 troops arrived in the French port of Marseilles in July 1918. In addition, the service of soldiers from the British and French colonies clearly globalized the Great War. The use of some 485,000 non-white soldiers from the French colonies and 160,000 from the British colonies in Europe is a constant reminder that this war, already in its initial phase, had acquired a global significance.

The Indian Army during World War I contributed a large number of divisions and independent brigades to the European, Mediterranean and the Middle East theatres of war. In total at least 74,187 Indian soldiers died during the war, fighting against the German Empire in German East Africa and on the Western Front. Many Western Jews hoped that Britain would have to accept foreign soldiers from her colonies India, Japan and Sinhalese (Sri Lanka) as equal combatants, thus making amends for what Britain as a colonial empire had done to colonized people and was still doing in April 1916 in Ireland when brutally crushing the Easter Rising and executing its leaders. Belonging to a persecued minority Jews raised the question which power could be trusted as a safeguard of humanity. Is the war, perhaps, a trial by ordeal, a Judgement of God, by which the loser, Tsarism, as man Jews hoped, would become apparent as the guilty party, and by which the winner of the fight (German-Austrians) would be proclaimed to be right? Alliances that may seem strange to a contemporary, were still possible.

The German-Jewish diplomat and historian Max von Oppenheim (1860 - 1946) who had been a frequent traveller to the Orient argued for enlisting the Ottoman Sultan, Mehmed V. to call on the world's Muslims to engage in a Holy War against the colonial powers France, Great Britain and Russia (Heather Streets-Salter: 38). In Oppenheim' view, Islam could become one of Germany's most important weapons with Germany trying to revolutionize the Islamic territories of her enemies and to undermine their colonial rules. Turkey, Germany's ally, 
could threaten Egypt and negatively influence British control of India (Xu Guoqi: 3). Thus the global character of the Great War was enhanced by the expansion of the war into the Ottoman Empire (involving large parts of the Middle East from the Russian Caucasus down to Syria, Palestine and Egypt). Even neutral countries were affected in the Great War: The Dutch Colonial Empire depended on the British and Japanese goodwill, and Dutch ships in the East Indies were checked by the Allies (Hubert P. Van Tuyll: 2; Heather Streets-Salter: 92).

The Dutch East Indies, consisting of what is now Indonesia, was home to a sizeable German population that worked to coordinate and finance covert operations designed to undermine British colonial rule and economic interests in Southeast Asia, and produced pan-Islamic, anti-British propaganda that was sent to Muslim-majority British Malaya, and also to India. The German and Turkish consuls in 'Batavia' regularly published statements about Britain's anti-Muslim orientation, as evidencd by the fact that they were at war with the Ottoman caliphat (Heather Streets-Salter: 106). Europe was deeply involved, and diasporic Jews followed the global events, as their journals show: The most important Zionist journal was Die Welt. Another German-Jewish journal was Ost und West, a German illustrated monthly that meant to bridge the Western, modernised Jewish world and the Eastern European Jewish world. The journal had a tremendous impact by familiarizing the German Jews with the sites of biblical stories. It frequently reported on the changing situation in Palestine, e.g. the Evelina de Rothschild School in Jerusalem, named after the British Jewish banker Lionel Nathan Freiherr de Rothschild (1808 - 1879), and schools founded by French Alliance Israélite Universelle, colliding with entrenched religious prejudices and replacing both the rabbinical TalmudTorahs and their counterparts, the Arab madrasas.

\section{EASTERN EUROPE AND ANTISEMITISM}

The Czarist regime for many German Jews represented the dominion of antisemitism (Wertheimer: 11ff.). When the Jewish neo-Kantian philosopher Hermann Cohen, the proponent of a Jewish religion of reason (Albanis: 28f.), toured Lithuania (Vilna=Vilnius) and visited Petersburg, he called Russia the "Land des grausamsten Antisemitismus")=the country of the most brutal antisemitism). The events (pogroms, persecutions, emigration waves) of the 'Knutokratie' (the rule by the whip) were closely observed and reported on in GermanJewish journals and newspapers, and emigration from Russia was recommended. Jewish journals advertised sea-
Figure 2. The steamer line Hapag (=HamburgAmerikanische Packetfahrt-Actien-Gesellschaft=HamburgAmerican-paket-transport society) advertised voyages to New York, Philadelphia ... with the Jew Albert Ballin (1857 - 1918) becoming the sometime general director of the HAPAG in 1899. The shipping companies profited from mass migration with 700000 Jewish transmigrants between 1905-1914 (Wertheimer: 13f.)

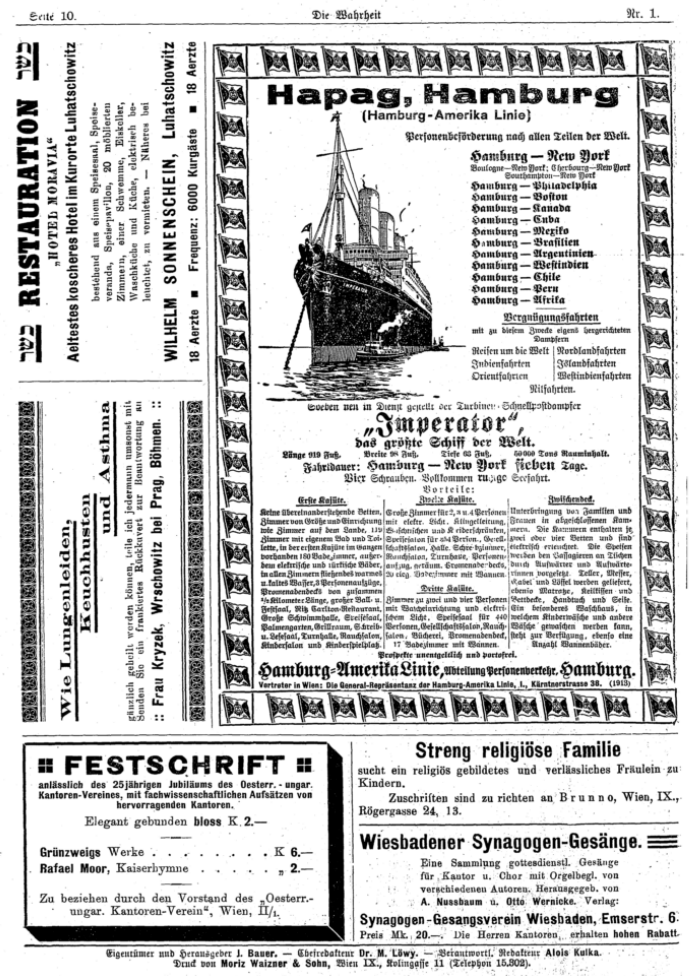

UB $D F G$

Source: Die Wahrheit=The truth-1914 in https://sammlungen. ub.uni-frankfurt.de/cm/image/view/3076039?w=904\#-

voyages (figure 2). An outbreak of anti-Jewish pogroms occurred in Russia in the early 1880's with repercussions resulting in almost two million Jews emigrating out of Russia from 1881 to 1914 out of 5,189,401 Jews in Russia, impacting Germany in particular (Wertheimer: 27ff.; Mendes-Flohr: 380ff., 408, 416). One of the leading literary historian and Shakespeare-expert, Stephen Jay Greenblatt (born November 7, 1943) remembers his family-life.

"I am an American who thinks of himself (interchangeably, with increasing degrees of specificity) as an Eastern European Jew, an Ashkenazi ${ }^{1}$ and a Litvak ${ }^{2}$, 
but this self-identification, I have to acknowledge, is strange. It is true that my grandparents were born in Lithuania: my father's parents in Kovna ${ }^{3}$, my mother's in Vilna. But they left for America sometime in the early 1890 s, and, with a single exception, it was more than a century before anyone in my family returned for a visit. No one seems to remember the precise year of their departure or even the precise occasion, though there was somewhat vague talk, when I was growing up, about the need to escape a tsarist Russification scheme that centred on drafting eligible young Jewish men into the Army for 25 -year terms of military service. I know that the Russian Government lurched between wanting to isolate Jews in a carefully demarcated Pale of Settlement, as if they were a dangerous virus, and wanting to swallow and absorb them by destroying their separate identity.

... My grandparents must, in any case, have had very little stake in staying in Lithuania: they were young and poor, and they had relatives who had already ventured off to the New World and sent back encouraging reports, along with money to help pay for their passage. I have no doubt that they wanted to maintain their religious identity: they lived out the rest of their lives as reasonably pious, observant Jews, keeping kosher homes, going to shul ${ }^{4}$, sending their sons to cheder ${ }^{5}$, saying Kaddish ${ }^{6}$ for their dead. But they left Eastern Europe not only and perhaps not principally as religious refugees; they were economic migrants, participating in a vast movement of populations from the stagnant economies and closed communities of Eastern and Southern Europe to the vibrant, shifting, unstable, largely unregulated society of the United States.

... They left quickly and illegally - in the case of my maternal grandparents, escaping across the border hidden beneath the straw of a peasant's wagon - made their way to a port city, sailed seasick and miserable in steerage, passed through Ellis Island, and headed off to wherever they had contacts with those who had preceded them. On landing in the New World, my relatives stayed in the cities of the North-East - Boston, New York and Montreal. (This allows us to say with some confidence that they were not leaving Lithuania because of the climate.) There were only two exceptions. One couple evidently boarded the wrong train and wound up in Savannah, Georgia, where in a scant generation they became drawling Southerners with dubious opinions about race relations and strong regional enthusiasms.

... Another relation ventured out west, with his wife and two small children, to try his hand as a pedlar in Wyoming. This was the occasion of the unique return to Lithuania to which I have alluded: after some years in what must have been a singularly raw and difficult environment, the pedlar's wife, declaring that it was simply too difficult to get kosher meat, returned with her daughter to Vilna. This was not, in historical perspective, a wise decision. The pedlar became the wealthy and successful owner of a department store in Cheyenne, which he left to his son. Decades passed and, in the late 1930s, the son, who remained unmarried all his life, received a letter in Yiddish $^{7}$, written in a shaky hand by the mother who had abandoned him. She begged him to send money for his sister's passage to America, but, emotionally wounded and ambivalent, he delayed, and subsequently both his mother and his sister perished in the Holocaust. But it was not any premonition of world-historical disaster that drove my relatives away from Eastern Europe, nor were they determined, like the Hasidim, the Amish, or for that matter the Puritans, to cling tenaciously in the New World to a strictly separate mode of life. To be sure, my grandparents lived in a predominantly Jewish neighbourhood - now a predominantly African American neighbourhood - and they attended a shul whose chants and customs greatly resembled what they would have known in Lithuania. At home they spoke their fantastically expressive Yiddish, rich in curses, charms to ward off the evil eye, and terms of endearment. The women cooked the heavy, heart-attack inducing food - flanken, kreplac $h$, tzimmis, zoyas, blintzes ${ }^{8}$, and chicken soup glistening with droplets of schmaltz ${ }^{9}$, - that had delighted and killed off their own parents and grandparents. And they clung to a set of distinctions that seemed, by the time I encountered them, as mysterious, impenetrable and irrelevant as the differences, savoured by Italians, among Genovese, Milanese and Torinese. Somehow my father always seemed to know, as if by occult signals, not only whether a person in the news or a performer on stage or someone he had just met was Jewish but whether he was Litvak, Galitzianer or Russisher, fine distinctions that seemed to matter to him, though I could never figure out why or in what way. When I was growing up, it seemed particularly absurd to me that, because her parents had come from Vilna rather than Kovna, my mother, born in Boston, somehow regarded herself as ineffably superior to my father, also born in Boston, and still more absurd that my father seemed to accede to this distinction. But, in retrospect, I recognise that these distinctions were signs that the inner world of Eastern Europe had survived for a half-century after the exodus. It had survived, but it was fading fast. My grandparents came to America to improve their lot, or, more accurately, to make it possible for their children to do so.... (Stephan Greenblatt)". 


\section{LANGUAGE-BARRIER}

One of the problems the Jews from Eastern Europe faced was the language-barrier, because many of them only spoke Yiddish, a Germanic language, resembling older German, which due to immigration was to find its way into the American language. Yiddish was the medium of daily conversation for men and women and the language in which most women prayed and read (Roshwald: 91), spoken by app. 7000000 Jews during the Great War.

The German-Jewish philosopher Moses Mendelssohn of the Enlightenment of the $18^{\text {th }}$ century, trying to deghettoize Jews, had tried to eradicate the 'Judeo-German' Yiddish language, making it become a synonym for pre-modern, obscurantist and irrational Judaism, the very antithesis to culture, and the obstacle to an upright human being (Aschheim1: 18; Grosmann: 75ff.; Mendes-Flohr: 402). Mendelssohn's antipathy was shared not only by the highly influential German-Jewish historian Heinrich Graetz (Aschheim1: 12), but found its unwilling support in a language-policy that tried to homogenize culture, e.g. by forcefully russifying (or polonising) the territory. But Yiddish was also disliked by the Zionists who favoured the Hebrew language. The question is ultimately linked to fundamental questions of Jewish identity: How can we maintain our identity in the face of dispersion and adversity? What is our proper language? Which ancestral traditions should be retained? Where do we belong? What is our homeland? The cataclysm of the Great War intensified the struggle over Jewish self-defnition and accelerated the crystallization of new competing forms of cultural expressionn and political action among Jews (Aviel Roshwald: 89).

\section{IDENTITY CONFLICTS}

The Jews as a diasporic entity fought on both sides of the Great War and were involved in opposing and hostile armies, serving in the armies of each of the belligerents (Aviel Roshwald:89; Berkowitz: 8ff.), making them not only a cannon fodder, but, by taking arms against one another, making them guilty of fratricide. Approximately a million and a half Jews fought in World War I for their respective countries. On the Allied side, at least 500,000 Jews served in the Russian Army, notwithstanding widespread Russian anti-Semitism and distrust of Jews. After the United States enters the war, U.S. forces got something like 250,000 Jewish soldiers. About 40,000 or so throughout the British Empire fought for Britain. And about 35,000 soldiers for France. The Jews, altogether making up 11000000 people, were in an intricate dillemma. Which side can best serve their interest in equality and freedom from persecutions and pogroms? At the beginning, many Jews began to pray for the victory of the Central Powers, hoping for the end of tsarism. Almost 100,000 Jews were serving in the German army whose political leaders saw the Jews that spoke the Germanic Yiddish as a bulwark against non-German culture and outpost of German economy.

The Jew Max Bodenheimer in August 1914 proposed to the German Ministry of Foreign Affairs to destabilize Russia and to found an East-European State (East Sea to Black Sea) in which the Jews would cooperate with the Germans. The state should be a bufferstate between Poland and Russia with the Jews linked to German language and culture cooperating with the German Reich. Also Zionists believed in the protection of the Ostjuden by the German army and the Germany army thought of utilising the Eastern Jews (=Ostjuden). The German Committee for the Freeing of Russian Jews (German: 'Deutsches Komitee zur Befreiung der russischen Juden'/then changed into 'Komitee für den Osten'), created on the $10^{\text {th }}$ of August, 1914 by Franz Oppenheimer, Adolf Friedman, Max Bodenheimer and Leo Motzkin lobbied for the socio-political liberation of Jewish people living in the Russian Empire and ensuring their protection from pogroms. The committee was supported by the German Empire. Was it not in the best of German interest to utilize the Eastern Jewish population, their quest for knowledge, and also their practical (e.g. tailoring) skills? Would the German support of Jews not be a fair compensation for the injustice and cruelty done to them by medieval Germany (e.g.: Crusades and pogroms, ritual murder libels, claming that Jews require human blood for the baking of bread for Passover).

In response to the Eastern Jews-question and the effort to gain influence in the United States, German authorities were willing to work closely with and support Jewish organisations. In 1916, before the decisive Balfour Declaration (the $2^{\text {nd }}$ of November, 1917), in which the British government decided to endorse the establishment of a Jewish home in Palestine, thus securing Britain's strategic interest in the Near East (Martin Sicker: 135). the question could still be asked, if Germany and Jews are not predestined allies in the fight against the destructive British-USA hegemony whose defeat would be in the interest of an independent Europe, and establish a global counterweight against the Anglosaxon Empires (Isaiah Friedmann: 288ff., Martin Sicker: 134ff.). Could the Zionist aspirations not be instrumentalized as a force against the Anglosaxons and the Entente war efforts? But then everything changed, and Jews switched the sides in favour of the Western allies. Eventually, the German 
War Ministry caved in to the pressure from the right and ordered a "Judenzählung" (Jewish census) in October 1916, a statistical survey of Jewish involvement on the front, implicitly accusing them of being draft-dodgers, and in 1918 had fatally imposed a "Grenzsperre" (=closing of the borders to the German East) which curtailed the entry of Jewish refugees (Aviel Roshwald: 103f.; Aschheim1: 183f.) who were seen as rivaling jobseekers. The German declaration from the $18^{\text {th }}$ of January, 1918 for the protection of Eastern Jews, their minority rights, and for the support of the Zionist cause, though welcomed by German Zionists (e. g. Franz Oppenheimer), rather came too late (Martin Sicker: 134f.). Even Germany's support of Lithuania's independence in 1918 (the $16^{\text {th }}$ of Februarycf. Mendelssohn: 113f., 219), and Germany's guarantee of Jewish rights in Lithuania from July 1918 (civil equality, freedom of religion and care of cultural development and traditions) as an antidote to the long Tsarist repressions, could not change the course of history (Marcos Silber: 126ff.,143ff.; Mendes-Flohr: 372ff.).

The common experiences in the trenches had not overcome antisemitic prejudices which centred around the accusation of the Eastern Jews being usurers ("Wucherer"). Many Jews, both from the West and the East, felt betrayed by Germany and her claim to Human Rights. The Jewish hope for close cooperation with Germany was crushed. Many Jews saw the only solution to the rampant antisemitism in a migration to Palestine and joined the allied forces by forming the Jewish Legion (1917-1921), referring to five battalions of Jewish volunteers, the 38 th to 42 nd (Service) Battalions of the Royal Fusiliers, that was raised in the British Army to fight against the Ottoman Empire during the First World War (Martin Sicker: 136f.) in the hope of founding an own state.

When the Great War broke out in 1914, the battles and the inherent political issues were eagerly observed and reported on by Jewish-German scholars and journalists who themselves represented the urban middle-class (and not necessarily the peddlars, cattledealers, and small businessmen). The encounters of Western with Eastern Jews raised (and re-ignited) the question of Jewish identity ('Oriental-Occidental', divide between the 'caftan' and 'cravat'-Jew) as (Emeritus) Professor of History at the Hebrew University, Steven E. Aschheim1, termed them in his provocative and most illuminous study, entitled Brothers and Strangers The East European Jew in German and German-Jewish Consciousness, 1800-1923, of the perception of the East European Jew in German Jewish consciousness, meaning the assimilated, prosperous, modernized and enlightened
Figure 3. Brothers and Strangers by Steven E. Aschheim
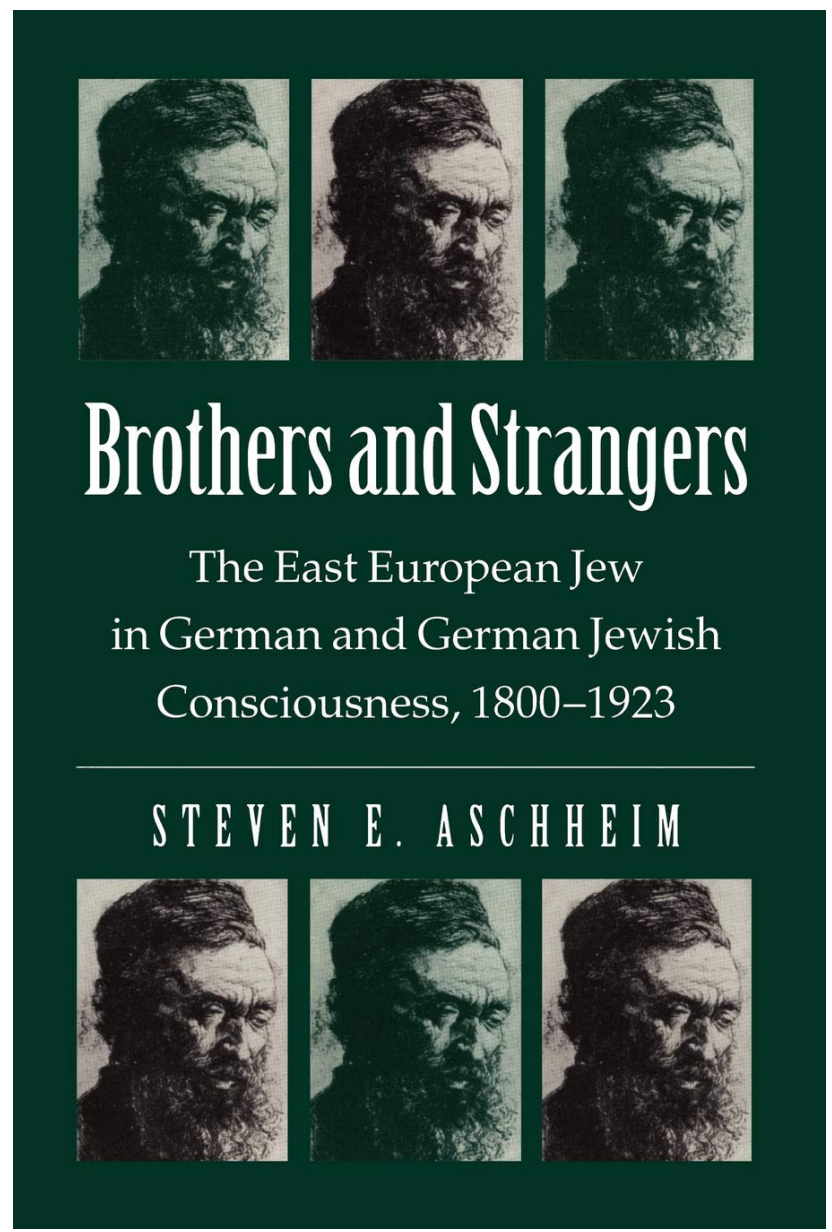

Source: https://images-na.ssl-images-amazon.com/images/ I/71sm1hiMHnL.jpg

Jewish community of Central Europe (Aschheim1: xviii; Wertheimer 3f.; Mendes-Flohr: 373; Berkowitz: 13ff.) and the segregated, impoverished Jewry of the East (figure 3), who appeared for many to be (semitic) 'conservative' Orientals or even half-Asians (Aschheim1: xxvi, 12, 20) who still had their different and alien customs (e.g. sidelocks, early marriage age, pre-arranged marriage, high fertility-rate, rote-learning), and appeared to look nonEuropean (e.g.: thick prominent lips, receding forehead and chin, large ears, curly black hair, dark skin). This problem was debated during the Great War in Germany under the discriminatory heading of the 'Ostjudenfrage' (=Eastern Jewish question), involving fairly familiarsounding topics like antisemitism, border control, chain migration, conspiracy theories, demographics, group identity, immigration policy, mass immigration, race, and zionism (Wertheimer: 6ff.). The Jews fighting 
for the Central Powers were embarrassed to see their Eastern brothers and sisters, especially since they had only recently become familiar with a new approach to athletics (e.g.: gymnastics, soccer), articulated by the Zionist Max Nordau whose concept of muscular Judaism sought to create Jewish heroes with 'deep chests, nimble limbs and fearless looks' (Dorsey James Michael: 42; Boyarin: 37ff.), ironically modelled on the Aryan ideal with physical prowess becoming a way of emancipation and an antidote to spiritual one-sidedness (Sander L Gilman: 256) ).

The fact that the Jewish people originated in the Orient as well as the presence of real Jews in the contemporary Orient aroused contradictory feelings among European Jews of identification and alienation. Some scholars claimed that the contrast was one of (Western) secular intellectualism, empty yearning ("life in deferment and exile"), and melancholy, a "saturnine proclivity" (Moshe Idel:9), on the one hand, and (Eastern) exaltation, fullness, plenitude, spirituality and joy, enthusiasm, on the other hand. Could a great experience, as experienced by the Eastern Jews, not overcome the lamentable control of the secualarized brain and make onself surrender to necessities of the heart? From this perspective Eastern Judaism appeared as a mode of overcoming mechanic and heartless Western modernization, a kind of psychological compensation. The insistence on the return to Jewish sources as attributed to the East became acute in the Great War and the obvious collapse of Western civilization on the slaughter-fields in Europe.

Disillusionment with the West made some Jews become enemies to Europe and devotees of the Orient. Were the Western Jews not traitors to their ancestral tradition? Whereas German Jews, from the Enlightenment on, stressed the fundamental compatibility of their Judaism with German culture and "Germanness," Martin Buber and others, such as Arnold Zweig and Gershom Scholem, emphasized Jewish distinctiveness and difference and did not want to give up the irrational forces, thus showing their willingness even to transvaluate myths or pantheism. Vitality and dynamism were central to them. The Jew was now cast as an "Oriental," or at the very least as a mediator between Europe and the Orient. With the early publications by Martin Buber in 1913 (Vom Judentum Ein Sammelbuch, 1913, Lepizig, Kurt Wolff Verlag) the question of the Jews as Orientals and their mythopoetic power was emphasized and became urgent, though there is no denying the dichotomy of Western against Eastern Jews involves difficult epistemological questions, since, as we know from the work of Edward Said, the construction of the East or, for that matter, the Orient tells us much more about those doing the constructing than those being constructed, and has less to do with the East than it does with the imaginations of the West whose views shifted from distance to self-affirmation that embraced the Eastern heritage in rebellion against the bourgeois West, as exemplified in the founder of kabbalitis research, Gershom Scholem (Biale: $31 \mathrm{f}$.).

Again, European society, in perceiving itself as civilized, rational, and progressive, caricaturized the Eastern world as exotic, backwards, undeveloped, and incapable of reason. The polarity between the enlightend West and the traditional East, underlined by a metaphorical pathology of decadence and sickness, sometimes even re-evaluating the communal tie of 'blood', was a clash of cultures with the war-leading Germany playing a siginificant role, as it borders on Poland as one of the heartlands of Eastern Judaism and fought there. When Germany managed to establish a military government, the Supreme Command of All German Forces in the East (Oberbefehlshaber der gesamten Deutschen Streitkräfte im Osten-Ober Ost for short) in 1914 in Eastern Europe, also in Lithuania, the ensuing encounter of German soldiers with Eastern Jews, living in their non-urban shtetls (=Yiddish for the diminutive form of shtot, "town"), raised the Western Jews' interest in their 'brothers' and 'sisters'. The plight of East European Jewry acquired great political urgency as German-Jewish soldiers on the eastern front discovered the immense suffering and squalor in the ghettos and could read about their plight in Yiddish-written newspaper in the relatively tolerant atmosphere of the German occupation (Aviel Roshwald: 112ff.) that even permitted the emigration of Jews to the USA (Manfred Nebelin: 194).

Jewish journalists and writers stationed in the Eastern Europe described the devastating effects of the war on East European Jewish life while those in Germany wrote about the grim situation on the home front. Solidarity with the Ostjuden often betrayed antipathy toward the bourgeois values of liberal German society that lacked the community-life, the religious intensity and spirituality, but also the liberating humour of Eastern Jewry. Whereas the previous generation of German Jews expressed shame over their eastern counterparts, their own children were embarrassed by the materialism and individualism of their parents and looked eastward for a source of renewed pride. This "cult of the Ostjuden" criticized both assimilated Jews and Western Zionists who flirted with East European Jewish culture as an abstraction but remained estranged from the reality of their own people. 
Figure 4. Painting by Hermann Struck

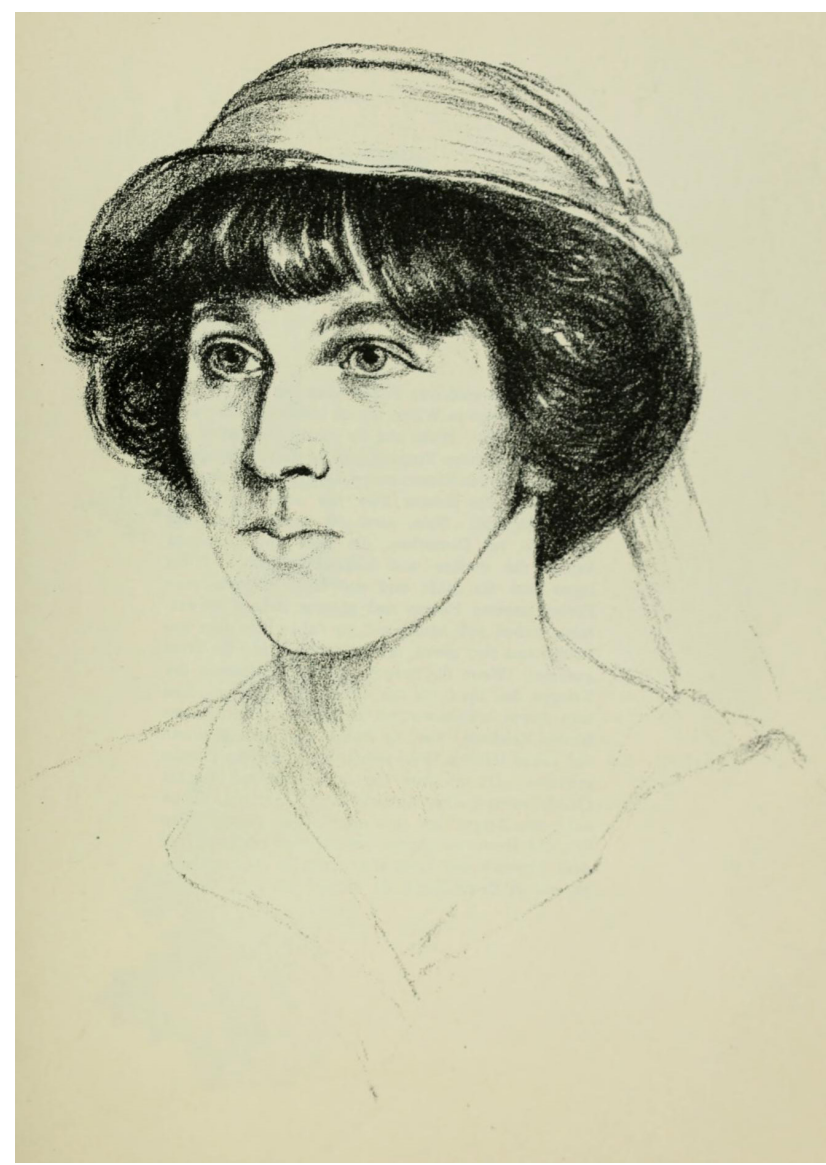

From: Hermann Struck \& Herbert Eulenberg, Skizzen aus Litauen, Weissrussland und Kurland, Verlag von Georg Stilke, Berlin, 1916, p. 32f.

Rachel ("Sie versteht nichts von Politik, gamichts. Das ist ihr viel zu

langweilig. ... Ihre großen schwarzen Augen haben so viel gelesen. Sie schauen ganz erwartungsvoll in die Welt und das Leben ... Aber es ist ja alles so traurig, so traurig auf der Erde. Da geht sie ans Klavier und spielt: Einen schwermütigen

Tanz von Chopin ... Finster zieht sie die orientalischen Brauen in die Höhe und ein paar Tränen fallen auf die Tasten des Klaviers. Eine Anverwandte kommt herzu, schaut sie an und fragt neugierig: "Hast Du geweint, Rachel?" Gleich hört sie auf zu spielen und klappt den Deckel zu. "Du bist wohl meschugge? Ich denke nicht dran. Das Leben ist in Prosa geschrieben. "=From politics she does not understand anything. It is much too boring. Her large black eyes have read so much. Full of expectations they look at the world and life ... But everything is so sad on earth.Then she goes to the piano and plays: a gloomy dance by Chopin. ... Gloomily she raises her oriental eye-brows and some tears fall on the keys of the piano. A relative approaches her, looks at her and asks curiously: ,Have you wept, Rachel.' Immediately she stops playing and closes the lid. ,Are you crazy? Life is written in prose."“- She avoids the eye-contact with the reader which reinforces her isolation.

Contrast it with this one:

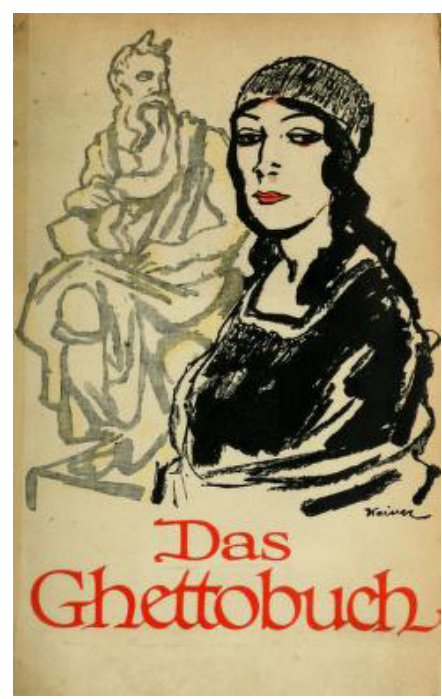

The conflict between modernity and tradition is illustrated in: Artur Landsberger, (1914). Das Gettobuch Die Schönsten Geschichten aus dem Getto. München: Verlag Georg Müller. On the cover of the anthology a young woman can be seen, depicted in three-quarters portraiture, her face in oblique profile, so that the black lines of the drawing emphasize the striking features of her countenance. She is full of self-confidence. From beneath her cap the long black tresses fall loose over her shoulders this being a hallmark of unmarried Jewesses. Behind her is another figure, likewise drawn in black albeit in a spectral and suggestive fashion, which is an imitation of Michelangelo's sculpture of Moses with the Tablet of Commandments. Source: https://ia800202.us.archive.org/BookReader/ BookReaderImages.php?zip=/10/items/dasghettobuchdie00land/ dasghettobuchdie00land_jp2.zip\&file=dasghettobuchdie00land_ jp2/dasghettobuchdie00land_0005.jp2\&scale $=8 \&$ rotate $=0$

As the German administration needed experts, e.g. interpreters, they utilized them, especially when an Office for Jewish Affairs was established. The German authorities saw them on the account of the similarity between Yiddish and German as intermediaries to the local people. Like many thousands of other Jews, and in the general popular enthusiasm for the war, at its outbreak the Jewish painter Hermann Struck (1876 in Berlin - 1944 in Haifa) Struck had volunteered for armed service. After brief duty on the front, he was installed in the press bureau of the Eastern High Command, which was stationed in Lithuania, first in Bialystok and then Kaunas. Here he functioned as censor and was a translator of Yiddish for the German army in Lithuania and the consultant for Jewish affairs to the German administration, and painted many Eastern Jews (figure 4), many of them physically battered and weary, but whose eyes and facial expressions bespoke 
an inner resilience, an uncompromising ability to remain true to themselves (Aviel Roshwald: 109). Knowing the Jewish quartes from London, Berlin, Paris, Rom, New York and other large cities he found the quarters in Wilna incomparable. Seeing a young girl walking amid the poor tenants of the house he wondered what might become of her when offered bread on the road, and felt disgusted at the distanced (="fischblütige") intellectuals writing their dispassionate treatises on prostitution. Together with the non-Jewish German writer Herbert Eulenberg (1876 - 19459) he composed sketches and accompanying texts to expose a German audience to Jewish life in the easternmost region of the Russian Empire (Skizzen aus Litauen, Weissrussland und Kurland). Their contributions were in line with a reappraisal of Eastern Yiddish-speaking Jews. Instead of seeing the Eastern Jews' maintenance of Yiddish as backwardness one should see it as a sign of their loyalty to their ex-fatherland or as an expression of cultural autonomy with Yiddish having become almost a lingua franca spoken in Russia, America, South-Africa, Syria, and Australia. Especially 'Wilna' (=Vilnius) ${ }^{10}$ around 1916 became the pride of Jews, referred to as the 'litauische Jerusalem' (=Lithuanian Jerusalem), where you could experience community, mutual help and a still functioning family-life that invites a poor guest on Sabbath. Will this life that resembles Oriental traditions become a prey to assimilation and secularization with sons revolting against their parents, seeking commercial contact with the outside, and daughters leaving for the city and both genders favouring mixed marriages with Gentiles?

Another person stationed in Wilna was the German writer Arnold Zweig who together with Hermann Struck wrote the book Das ostjüdische Antlitz (1919), published by Zionist publishing house, which promoted the idea of a cultural renewal of Jewry as initiated by Martin Buber's notion of a Jewish Renaissance. Zweig portrayed East European Jewry in mythic terms as the living embodiment of an authentic Jewishness upon which Zionist renewal was to be built believing that the 'Jewish individual is indestructible, not to be deformed and not to be diverted from the path of goodness, warmth and sincerity'. He questioned the cultural values of the West (e.g. punctuality) (Aschheim1: 202) and expressed a yearning for the East (Moshe Gresser: 136). Eastern Jews contended with their burdensome material existence by living their real lives in the world of liturgy, the mind and spirit, especially on the Sabbath. Eastern Jews could even laugh amid all adversities and retain their dignity. Many areas were influenced and shaped by the Jewish dissident movement of Hasidism whose founder Ba'al Shem Tov
Figure 5. Mizrahi Jews

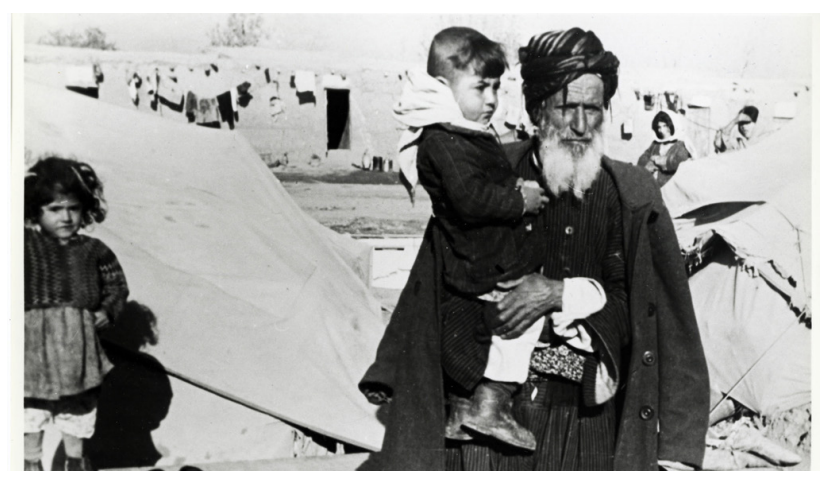

Source: https://www.myjewishlearning.com/wp-content/ uploads/2017/03/kurdish-refugees-4-cropped.jpg

had taught his followers to feel good and be joyful, not to deeply regret one's transgressions, encouraging storytelling, jumping, singing and dancing (Mendes-Flohr: 389f.). One famous person was the badchen (Yiddish for: badkhn=Hebrew word for jester) who entertained guests at weddings and paid tribute to the arousal of both laughter and melancholy. During the wedding dancing, for example, the badkhn might turn to the orchestra and say, "You musicians play really badly_I mean, well" ("Gor zeyer mis, meyn ikh zis").

\section{CONCLUSION}

Eastern Jewry proved to be highly dynamic and lively. Many Eastern Jews began even to look down upon the Western Jews, and were skeptical of the secularized Western Jews. Young Jewish intellectuals (e.g.: Siegfried Bernfeld, Martin Buber, Erich Fromm, Gershom Scholem) (Aviel Roshwald: 110ff.), preached courage and self-esteem. They felt impelled to examine the limits of assimilation and found in the arrival of the East European Jews a source of encouragement and inspiration. Here they found authentic Jewish culture and tradition worthy of emulation, that was deemed capable of reviving and nourishing Jewish life, giving perhaps a solution to their own identity crisis. The Eastern Jew thus became the embodiment of an authentic, intact Jewish culture that no longer existed in Germany and the West; the Western Jew could be associated with both highest technology - and highest depravity. Someone, it was argued, who uses soap for washing, can be more barbarian than a poor Eastern Jew who focuses on the holy scripture (Aviel Roshwald: 105).

The fundamental issue was how to urbanize rural 
people and modernize society without uprooting its people and destroying their basic existential pillars. Respect of cultural difference must be prioritized. Herein lies the current actuality of the "Ostjudenproblem" (=problem of Eastern Jews), as the Eastern Jews were not willing to give in to cultural homogenization and consumptive seductions. The programme of deorientalization, beginning with Western Europe's Enlightenment that, supported by Western Jews, orientalized East European Jews (=Ostuden) is still in use in Israel as directed by Ashkenazi Jews, many themselves of East European origin, against Arabs, the Palestinians and the Mizrahim (=Hebrew for Orientals=Jews from Arab lands, i. e. North Africa, the Middle East, and Central Asia: Khazzoom: 487ff., 501; Segev-figure 5) who are the new 'Orientals, held in paternalistic subjugation'. Situated in the heart of the Middle East, Israel today stands at the very epicenter of the putative "clash of civilizations." (Aschheim 2:21ff.) Many of the negative, backward characteristics that were previously applied to these East European Jews themselves were now directed at the Jewish masses from Arab countries who after 1948 poured into the new State. They should be infused with an Occidental spirit, and the Westernized Jews should not be dragged into Orientalism.

Is the presumed dichtomy between the West and the oriental East, the great chain of orientalization (Aschheim 2:22), one key to understanding the Arab/Israeli conflict (Khazzoom: 504)? It certainly accompanies the process of Modernity which in itself is a hotly controversial concept: Migration, leaving the shtetl, a metaphor for the traditional way of life of 19th-century Eastern European Jews, has its disadvantages (separation and destabilization of families, loss of direction, a break in tradition and language). This transformation requires, unless you despair of an open society and advocate a return to traditionalism and tribalism, both the familiarization of the host community with the alien-appearing customs of the new arrivals and of the latter's information on the majority's traditions, and a redefinition of the attitude towards the past and some kind of hermeutically active dialogue with the past, finding a way of both criticizing and retaining it (Dan Miron: 124f.). Modernity requires the conservation of the Old and shows that the derogatory construction of the 'East' is misleading. Are the narrow and twisting streets just backward or not popular exactly because of their intimate sidelines? Romantization seems to be the necssary, compensatory companion to Modernity? Can the differentiation into rational progress, today called globalization, on the one side, and traditional worlds, on the other side, be overcome, or must it simply be coped with?

\section{ENDNOTES}

1) Those Jewish settlers who established communities along the German river Rhine and in Northern France dating to the Middle Ages; contrasted with the Sephardi Jews (=Sephardim), who descend from Jews who settled in the Iberian Peninsula, and Mizrahi Jews, who descend from Jews who remainedew in the Middle East. Although Ashkenaz referred in the Middle Ages only to German lands, the term eventually included northern France and England as well as northern Italy and parts of Central Europe like Bohemia. As Jews migrated into the Polish-Lithuanian Commonwealth, the term broadened to include East European Jews as well. Jews of early Ashkenaz brought their spoken German dialect of Yiddish as well as local customs and practices of Jewish living into Slavic territories.

2) Name for Lithuanian Jew

3) In Jewish sources Kovna, Kovne; in Russian Kovno; in German Kauen

4) meaning school in Yiddish

5) traditional elementary school teaching the basics of Judaism and the Hebrew language.

6) a hymn of praises to God found in Jewish prayer services.

7) Yiddish is a Germanic language, originally spoken by the Jews of Central and later Eastern Europe, written in the Hebrew alphabet, and containing a substantial substratum of words from Hebrew as well as numerous loans from Slavic languages.

8) Yiddish words

9) Yiddish word

10) Several countries have laid claim to Vilna, and therefore it has been known by several names. Russians and Jews called it "Vilna." It was part of the Russian Empire until World War I. Following the War the city was seized by Poland. The Polish word for thecity is "Wilno." The Soviet Union captured the city and handed it to the Republic of Lithuania in 1939. The Lithuanian word for the city is "Vilnius".

\section{REFERENCES \\ Printed books}

Albanis, Elisabeth (2002). German-Jewish Cultural Identity from 1900 to the Aftermath of the First World War. Tübingen, Germany: Max Niemeyer Verlag.

Aschheim, Steven E. (1) (1999). Brothers and Strangers: The East European Jew in German and German Jewish Consciousness, 1800-1923: Madison: University of Wisconsin Press.

Aschheim, Steven E. (2) (2012). At the Edges of Liberalism: 
Junctions of European, German, and Jewish History. New York, Palgrave macmillan.

Berkowitz, Michael (1997). Western Jewry and the Zionist Project, 1914-1933. Cambridge, England: Cambridge University Press.

Boyarin, Daniel (1997). Unheroic Conduct. The Rise of Heterosexuality and the Invention oft he Jewish Man. Berkeley, Los Angeles, CA, and London, England: University of California Press.

Dingsdale, Alan (2002). Mapping Modernities Geographies of Central and Eastern Europe 1920-2000. London, New York: Routledge.

Dorsey, James Michael (2017). Shifting Sands: Essays On Sports And Politics In The Middle East And North Africa, New Jersey: World Scientific.

Friedmann, Isaiah (1977). Germany, Turkey, and Zionism 1897-1918, Transaction Publishers: New Brunswick, London.

Gilman, Sander L. (1991). Inscribing the Other. University of Nebraska Press.

Gresser, Moshe (1994). Dual Allegiance: Freud as a Modern Jew, Albany, State of University New York Press.

Grossman, Jeffrey A. (2000), The Discourse on Yiddish in Germany from the Enlightenment to the Second Empire. Rochester, USA: Camden House.

(ed.) Hutter (2013), Manfred. Between Mumbai and Manila: Judaism in Asia Since the Founding of the State of Israel: Bonn: University Press.

Guoqi, Xu (2017). Asia and the Great War: A Shared History, Oxford: University Press.

Idel, Moshe (2010). Old Worlds, New Mirrors, Philadelphia: University of Pennsylvania Press.

Mendelsohn, Ezra (1983). The Jews of East Central Europe Between the World Wars. Bloomington, IN: Indiana University Press Miron, Dan (2000). The Image of the Shtetl and Other Studies of Modern Jewish Literary Imagination, New York.

Mendes-Flohr, Paul R., Reinharz, Jehuda (1980). The Jews in the Modern World: A Documentary History. New York: Oxford University Press.

Nebelin, Manfred (2010). Ludendorff: Diktator im Ersten Weltkrieg, München: Siedler Verlag.

(ed.) Roshwald, Aviel and Stites, Richard (2002). European Culture in the Great War: The Arts, Entertainment and Propaganda 1914-1918, Cambridge: University Press.
Segev, Tom (1986). 1949 the First Israelis. New York:Free Press.

Sicker, Martin (1999). Reshaping Palestine: From Muhammad Ali to the British Mandate, 1831-1922, Westport, Connecticut London: Praeger.

Silber, Marcos (1982). Lithuania? But Which? The Changing Political Attitude of the Jewish Political Elite in East Central Europe toward Emerging Lithuania, 19151919, University of Wisconsin Press.

(ed.) Sirutavicius, Vladas and Staliunas, Darius (2011). A Pragmatic Alliance: Jewish-Lithuanian Political Cooperation at the Beginning of the Twentieth Century, Budapest, New York: Central European University Press.

Streets-Salter, Heather (2017). World War One in Southeast Asia: Colonialism and Anticolonialism in an Era of Global Conflict: Cambridge: University Printing House.

Van Tuyll van Seeroskerken, Hubert P. (2001). The Netherlands and World War I: Espionage, Diplomacy and Survival, Leiden, Boston, Köln: Brill.

Wertheimer, Jack (1987). Unwelcome Strangers. Oxford: Oxford University Press.

\section{Website article}

Biale, David (2001). Shabbtai Zvi and the Seductions of Jewish Orientalism Retrieved from https:// openscholar.huji.ac.il/sites/default/files/jstudies/ files/_file_1442397726.pdf

Greenblatt, Stephen (2000, September 18). The Inevitable Pit Stephen Greenblatt writes about his family and the New World. Retrieved from https://www.lrb. co.uk/the-paper/v22/n18/stephen-greenblatt/theinevitable-pit

The Jewish community of the Dutch East Indies Retrieved from https://theindoproject.org/the-jewishpopulation-of-the-dutch-east-indies/

Khazzoom, Aziza (2003, August). The Great Chain of Orientalism: Jewish Identity, Stigma Mangement, and Ethnic Exclusion in Israel. Retrieved from https:// www.uio.no/studier/emner/hf/ikos/MONA1300/v07/ Khazzoom\%20chain\%20of\%20orientalism.pdf 